\title{
Capacity for epithelial differentiation in synovial sarcoma: analysis of a new human cell line
}

\author{
T Yakushiji, K Yonemura, J Tsuruta, K Nishida, T Kato, K Takagi
}

\begin{abstract}
Aim-To analyse the capacity for epithelial differentiation in synovial sarcoma using a new human cell line.

Methods-A new human cell line, KUSS-1, was established from a monophasic, spindle cell type of synovial sarcoma by grafting those cells on to severe combined immunodeficient (SCID) mice and then transferring them to in vitro culture systems. The KU-SS- 1 cells were characterised by light and electron microscopy, and by immunohistochemical, flow cytometric, and cytogenetic analysis.

Results-Primary tumour and cultured cells at passage 20 showed a positive reaction for vimentin, which is a mesenchymal marker. After 40 passages, subcultured cells were injected into SCID mice to induce further tumours. These advanced subcultured cells and the tumour cells that they induced were positive for cytokeratin, an epithelial marker, and exhibited epithelial ultrastructural features such as intermediate junctions. Furthermore, two colour immunofluorescent analysis for proliferating nuclear cell antigen (PCNA) and intermediate filaments showed that a large number of PCNA expressing cells were positive for vimentin, and that part of this fraction also expressed cytokeratin. The existence of cells with reactivity for these three markers indicated that, in this cell line, a fraction with high proliferating capacity had both mesenchymal and epithelial markers. In addition, cytogenetically, this cell line expressed the SYT-SSX chimaeric transcript as a result of the $t(X ; 18)(p 11 ; q 11)$ translocation.
\end{abstract}

Department of Orthopaedic Surgery, Kumamoto University School of Medicine, 1-1-1 Honjo,

Kumamoto 860-0811, Japan

T Yakushiji

K Yonemura

K Nishida

T Kato

K Takagi

Department of Surgical Pathology, Kumamoto University School of Medicine J Tsuruta

Correspondence to: Dr Yakushiji email: teiji@kaiju.medic. kumamoto-u.ac.jp

Accepted for publication 29 November 1999
Conclusions-A human synovial sarcoma cell line was established and stably maintained in cell culture for more than 70 passages. In addition, this cell line showed epithelial differentiation, which supports the hypothesis that synovial sarcoma is a carcinosarcoma like tumour with true epithelial differentiation. This cell line will be a useful tool for investigating the nature of this tumour and will contribute to clinical studies.

(F Clin Pathol 2000;53:525-531)

Keywords: synovial sarcoma; cell line; carcinosarcoma; differentiation

There have been numerous reports on the clinical characteristics and biological behaviour of synovial sarcoma ${ }^{1-9}$ since its first description by Stuer in $1893 .{ }^{10}$ The name synovial sarcoma relates to the histological appearance of the tumour, but its histogenesis remains controversial. $^{35781112}$ Histologically, it is divided into two main types: (1) the monophasic type, and (2) the biphasic type. From the pathological and histological findings, various theories of its histogenesis have proposed the synovium, ${ }^{5}$ epithelium, ${ }^{37811}$ and neural tissue ${ }^{12}$ as origins. Pathological and morphological studies using xenotransplanted ${ }^{1314}$ or cultured human cell lines might help to elucidate the origin of synovial sarcoma but, because of the difficulty in establishing such a cell line, only a few cultured cell lines derived from synovial sarcomas have been reported..$^{15-18}$

We have established a new human synovial sarcoma cell line, named KU-SS-1, by grafting the parent tumour first on to severe combined immune deficient (SCID) mice and then transferring the tumour cells to in vitro culture systems. We designed our study to elucidate the nature of synovial sarcoma through the characterisation of the cultured cell line, and we described the characteristics with regard to morphology, antigenic markers, and cytogenetic analysis.

\section{Methods}

PATIENT AND SOURCE OF TUMOUR TISSUE A 27 year old Japanese woman with a synovial sarcoma in the right popliteal fossa underwent a resection in July 1995. The histological diagnosis of this tumour was a monophasic synovial sarcoma of the spindle cell type.

XENOTRANSPLANTATION

The tumour tissue from the resected sample was minced under sterile conditions. Then, $0.5 \mathrm{ml}$ of the minced specimen was inoculated into the subcutaneous space on the backs of 5 week old, male SCID mice (Nihon Clea, Tokyo, Japan). When the xenotransplanted tumour grew to $3.0 \mathrm{~cm}$ in diameter, it was transferred serially to the backs of additional mice.

CELL CULTURE

The minced tissue of SCID mouse supported tumours was prepared first by digesting with $0.05 \%$ trypsin (Difco Laboratories, Detroit, Michigan, USA) and $0.02 \%$ ethylenediaminetetraacetic acid in $0.01 \mathrm{M}$ phosphate buffered saline, $\mathrm{pH} 7.4$ (PBS). Approximately $5 \times 10^{6}$ cells were cultured in a $25 \mathrm{~cm}^{2}$ plastic culture flask (Nunc Inc, Naperville, Illinois, USA) in RPMI 1640 medium (Nissui Pharmaceutical, Tokyo, Japan) supplemented with $10 \%$ fetal bovine serum (Filtron, Brooklyn, Australia), $2 \mathrm{mM}$ L-glutamine (Wako Pure Chemicals, Osaka, Japan), $1 \mathrm{mM}$ sodium pyruvate, and $100 \mathrm{IU} / \mathrm{ml}$ of penicillin $\mathrm{G}$, under a humidified atmosphere of $5 \% \mathrm{CO}_{2}$ and $95 \%$ air at $37^{\circ} \mathrm{C}$. 
The culture medium was changed three times a week. When the cultured cells became confluent, they were trypsinised and subcultured in a $25 \mathrm{~cm}^{2}$ flask at a dilution of $1 / 3$.

CELL GROWTH IN VITRO

The growth characteristics of the KU-SS-1 cells were determined using cultured cells at passage 40 . Tumour cells $\left(1 \times 10^{5}\right.$ cells $\left./ \mathrm{cm}^{2}\right)$ were seeded in $3 \mathrm{~cm}$ plastic dishes. The average number of viable cells was determined by counting the cells in three dishes with trypan blue exclusion for seven days after starting the cultures.

TUMOUR FORMATION IN VIVO

The tumour formation in vivo of the KU-SS-1 cells was examined by heterotransplantation in 5 week old male SCID mice. Tumour cells at passage 40 of subculture were injected subcutaneously at an inoculum size of $8 \times 10^{7}$ cells.

LIGHT MICROSCOPIC EXAMINATION

After $10 \%$ neutral buffered formalin or $95 \%$ ethanol fixation, sections of primary tumour and SCID mice tumours, and cultured cells on Lab-Tek tissue chamber slides (Nunc Inc), were stained with haematoxylin and eosin.

IMMUNOHISTOCHEMISTRY

Immnohistochemical staining was performed using the avidin-biotin-peroxidase complex (ABC) method $^{19} 20$ (Vectastain Elite ABC kit; Vector Labs, Burlingame, California, USA). The monoclonal antibodies used were antivimentin (magnification, $\times 400$; Dako, Glostrup, Denmark), antiepithelial membrane antigen (EMA; magnification, $\times 50$; Dako), and anticytokeratin (AE1/AE3; magnification, $\times 50$; Progen, Heidelberg, Germany). ${ }^{21}{ }^{22}$ For EMA and cytokeratin staining in formalin fixed materials, additional technical procedures included digestion with trypsin $(0.1 \%$ in $0.05 \mathrm{M}$ Tris/ $\mathrm{HCl}$ buffer and $0.1 \%$ calcium chloride, $\mathrm{pH} 7.6$ ) for 30 minutes at $37^{\circ} \mathrm{C}$ before incubation with the monoclonal antibodies. ${ }^{23}$ The sections were incubated with each monoclonal antibody overnight at $4^{\circ} \mathrm{C}$, and 3,3'-diaminobenzidinetetrahydrochloride (DAB; Nacalai Chemicals, Kyoto, Japan) in $0.05 \mathrm{M}$ Tris $/ \mathrm{HCl}$ buffer, $\mathrm{pH} 7.6$, containing $0.01 \% \mathrm{H}_{2} \mathrm{O}_{2}$ was used for the visualisation of peroxidase activity.

ELECTRON MICROSCOPIC EXAMINATION

Tissues of the tumours and cultured cells were fixed in $2.5 \%$ glutaraldehyde for two hours and post-fixed in $2 \%$ osmium tetroxide for two hours. After dehydration in a graded series of ethanols, the specimens were processed through propylene oxide and embedded in Epon 812 (Polysciences Inc, Warrington, Pennsylvania, USA). Each ultrathin section was stained and observed with an HU-12A or an H-7500 electron microscope (Hitachi Electronics, Tokyo, Japan).

FLOW CYTOMETRIC ANALYSIS

Cells in suspension were fixed in $70 \%$ methanol for 10 minutes at $-20^{\circ} \mathrm{C}$, followed by $0.5 \%$ Nonidet P-40 (NP-40; Nacalai Chemicals) for five minutes in an ice bath, after which immunostaining and DNA staining were performed. $^{2425}$

A double staining method to detect proliferating cell nuclear antigen (PCNA) in combination with DNA content (by means of propidium iodide (PI)) was used. The fixed cells were incubated with fluorescein isothiocyanate (FITC) conjugated anti-PCNA monoclonal antibody (PC10; Dako) ${ }^{26} 27$ for 30 minutes. After washing three times with PBS, the cells were resuspended in $10 \mu \mathrm{g} / \mathrm{ml}$ PI (Nacalai Chemicals) solution containing $50 \mu \mathrm{g} / \mathrm{ml}$ RNase (Sigma Chemical Co, St Louis, Missouri, USA) and kept in the cold and dark for at least 30 minutes until analysis.

For the detection of intermediate filaments, two monoclonal antibodies were used: FITC conjugated anticytokeratin (MNF116; Dako) and FITC conjugated antivimentin (Serotec, Oxford, UK). Staining with two monoclonal antibodies (anti-PCNA and anti-intermediate filament) was performed using a direct two colour immunofluorescence technique; the fixed cells were incubated with the phycoerythrin (PE) conjugated anti-PCNA monoclonal antibody (Dako) and the FITC conjugated anti-intermediate filament monoclonal antibody for 30 minutes. Incubation was performed on ice, in the dark, using $1 \times 10^{6}$ cells, and all monoclonal antibodies were used at saturating concentrations. For flow cytometric analysis, a FACScan flow cytometer (BectonDickinson, Sunnyvale, California, USA) was used as described previously. ${ }^{25} 2829$

\section{CHROMOSOMAL ANALYSIS}

For the cultured cells at passage 30 , chromosome constitution was analysed with trypsingiemsa $(G)$ or quinacrine $(Q)$ banding according to the method described previously. ${ }^{30-32}$

\section{REVERSE TRANSCRIPTASE POLYMERASE CHAIN} REACTION

Using the reverse transcriptase polymerase chain reaction (RT-PCR), we analysed the chimaeric transcript, SYT-SSX, as a result of the translocation $\mathrm{t}(\mathrm{X} ; 18)(\mathrm{p} 11 ; \mathrm{q} 11)$, whose specificity for synovial sarcoma has been confirmed. ${ }^{33-35}$ RT-PCR was carried out as described by Clark et al. ${ }^{33}$ RNA was extracted from $1 \times 10^{7} \mathrm{KU}-S S-1$ cells at passage 45 using acid guanidium thiocyanate followed by phenol/chloroform extraction. The first amplification was performed with the following primers: 5'-AGG ACA GCA GCA GGG CTA CGG TCC-3' and 5'-TTT TGT GGG CCA GAT GCT TCT GGC-3'; in the second nested PCR, the primers used to amplify SYT-SSX cDNA transcripts were 5'-GTA TCC TAA CTA CCC ACA GGG ACA-3' and 5'-ACT TCC TCC GAA TCA TTT CCT TCC-3'. All primers were synthesised at Sawady Technology Inc (Tokyo, Japan). The RT-PCR products were separated on $2.0 \%$ agarose gels.

\section{Results}

CHARACTERISATION OF PRIMARY TUMOUR

Microscopically, the parent tumour was composed of rather small, uniform, spindle shaped 


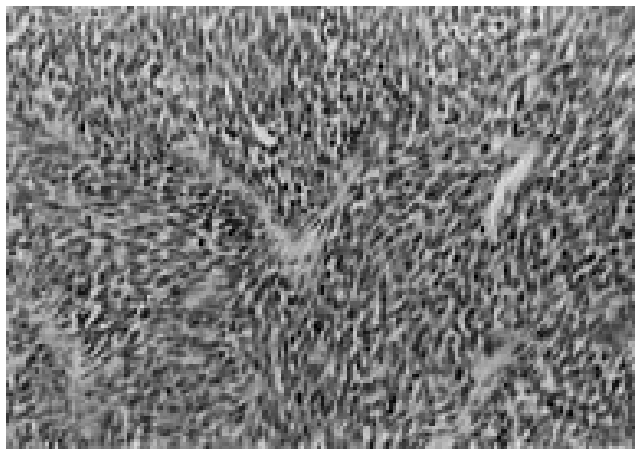

Figure 1 Light microscopic findings of the original tumour from the right popliteal fossa of a 27 year old woman. The tumour is composed of a compact proliferation of fasciculated short spindle cells, with a small amount of indistinct cytoplasm and dark staining oval nuclei, corresponding to the monophasic synovial sarcoma of spindle cell type (haematoxylin and eosin stained; magnification, $\times 400)$.

cells with a small amount of indistinct cytoplasm and dark staining oval nuclei (fig 1). The tumour cells showed intersecting fascicles in the growth pattern and exhibited one or two mitotic figures in each high power field. Immunohistochemically, the tumour was completely negative for epithelial markers (cytokeratin and EMA).

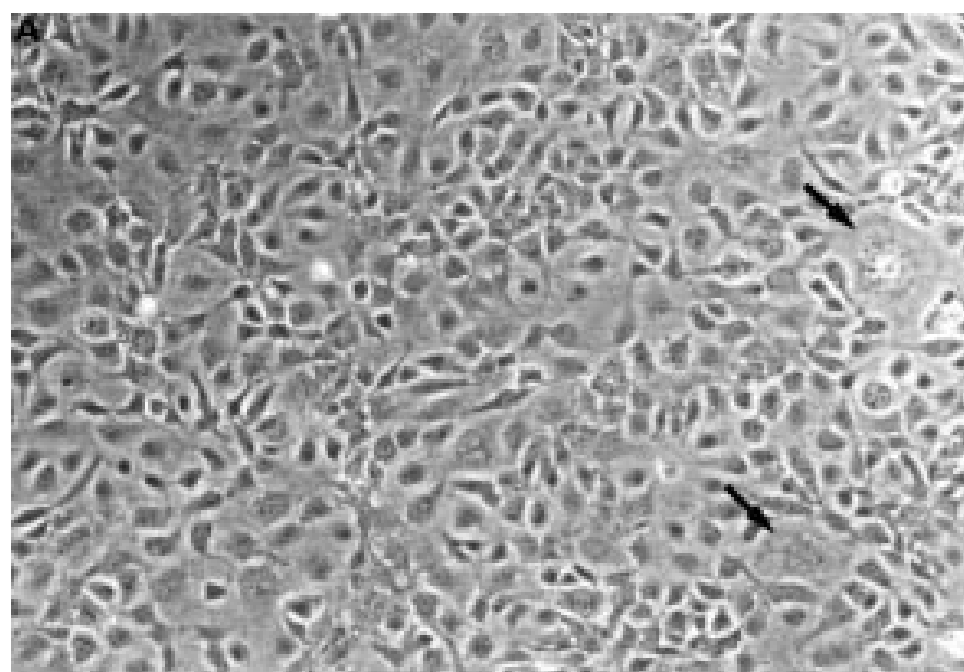

B
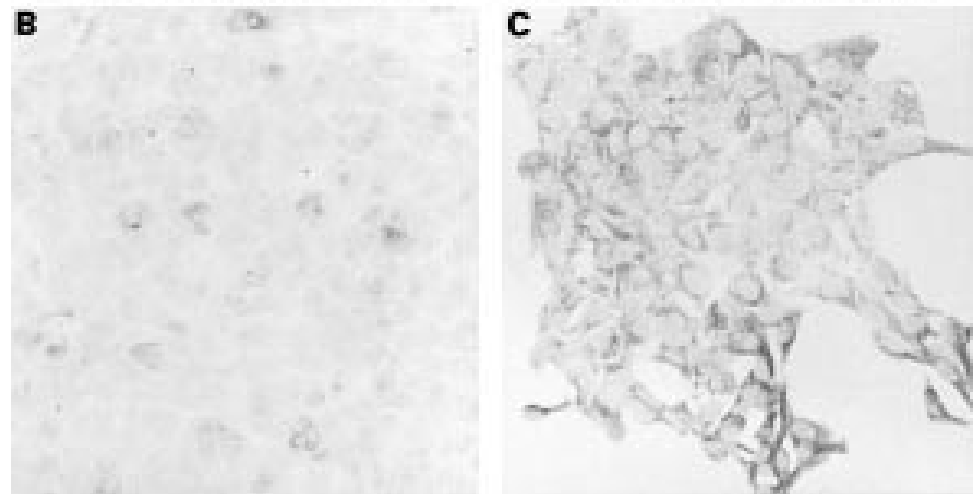

Figure 2 Microscopic observation of KU-SS-1 cells in vitro at passage 40. (A) Short spindle cells, polygonal cells, and a few multinucleate giant cells (arrows) growing in a sheet like pattern as viewed under an inverted phase contrast microscope (magnification, $\times 100)$. Positive reactions of the cultured cells with (B) an anticytokeratin antibody and (C) an antivimentin antibody (avidin-biotin-peroxidase complex method; magnification, $\times 200$ ).

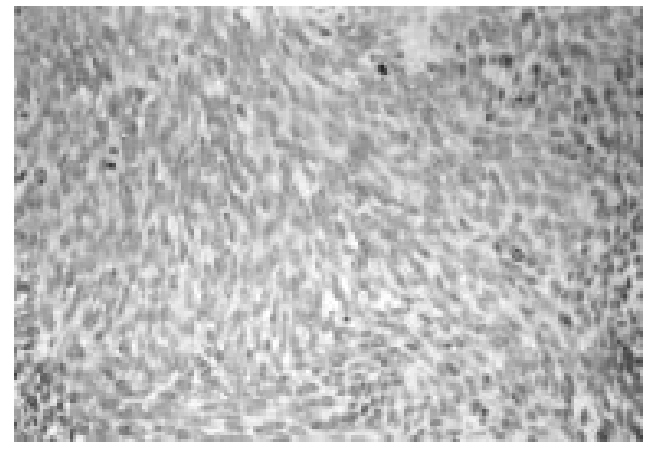

Figure 3 Light microscopic observation of a severe combined immunodeficient (SCID) mouse tumour induced by inoculation of the 40th subcultured KU-SS-1 cells. Immunohistochemical staining with anticytokeratin antibody (avidin-biotin-peroxidase complex method; magnification, $\times 400)$.

CHARACTERISATION OF IN VITRO CULTURED CELLS AT PASSAGE 20

Tissues from the tumour transplanted into SCID mice were cultured. A cell line designated as KU-SS-1 was successfully established from the third in vivo passage and has been stably maintained for over 70 passages in vitro.

At early passages in subculture, the growth of tumour cells showed a biphasic pattern composed of two different elements: one consisted of polygonal cells with centrally placed large nuclei, which joined together to form epithelial plaques; the other consisted of spindle shaped cells that had indistinct oval nuclei. The later, fibroblastic element filled the spaces between the bundles of polygonal cells.

Immunohistochemically, spindle shaped cells stained strongly with the antivimentin monoclonal antibody, whereas polygonal cells stained weakly, and most of the tumour cells reacted with anti-EMA but not with anticytokeratin.

\section{CHARACTERISATION OF KU-SS-1 CELLS AT} PASSAGE 40

The growth pattern of the cultured cells changed distinctly after the 30th subculture. Epithelial plaques gradually faded out, and the KU-SS- 1 cell line at passage 40 was composed of the proliferation in a sheet like pattern of (1) rather short spindle cells, (2) large polygonal shaped cells with abundant cytoplasm, and (3) a few multinucleate giant cells (fig 2A). The cells (at passage 40) proliferated with a doubling time of 93.8 hours.

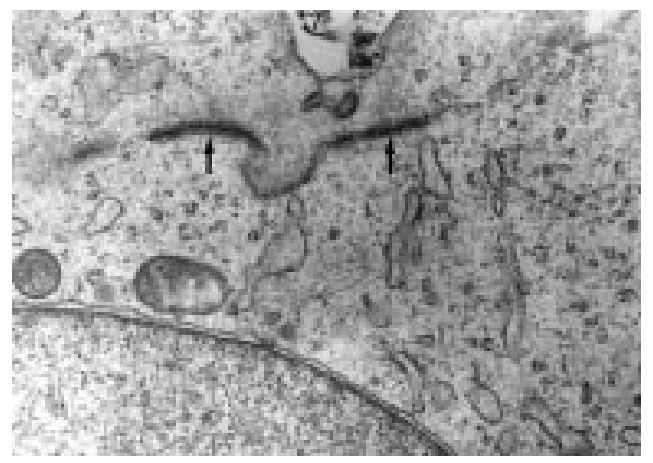

Figure 4 Electron micrographs of KU-SS-1 cells at passage 40. Close attachment to neighbouring cells with many intermediate junctions (magnification, $\times 31400$ ). 


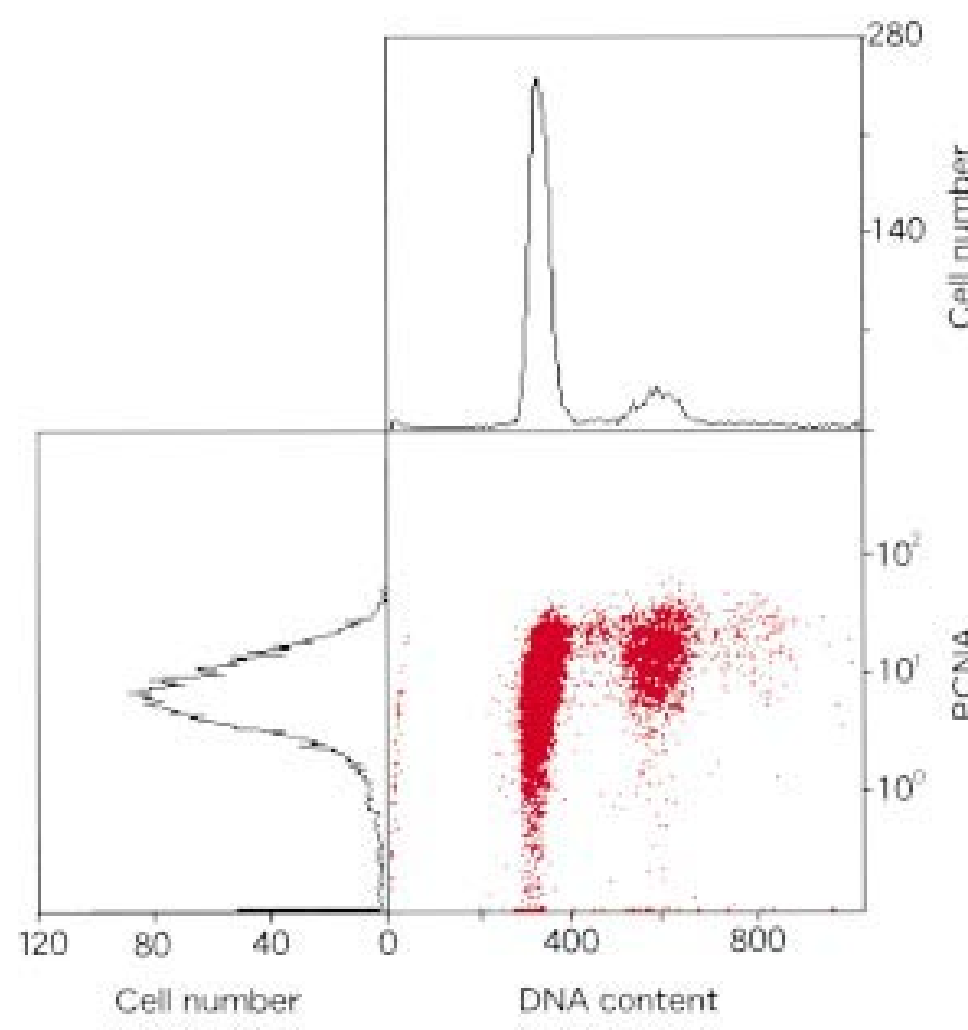

Figure 5 Contour plot and histograms showing proliferating nuclear cell antigen (PCNA) concentrations and DNA content (propidium iodide staining) of KU-SS-1 cells in logarithmic growth phase.
16 weeks after inoculation, tumour masses developed to a size of 10 to $15 \mathrm{~mm}$ in diameter. The histology of the tumour resembled the original one. Immunohistochemical findings revealed that the tumour cell was positive for cytokeratin (fig 3), EMA, and vimentin, whereas the original tumour was negative for cytokeratin.

ULTRASTRUCTURAL STUDY

Electron microscopic observation of the 40th subculture cells found that they did not contain many cytoplasmic organelles; however, many junctions were observed, including intermediate junctions or desmosome like junctions (fig 4). On the other hand, SCID mouse tumours derived from the inoculation of 40th subcultured cells showed the tumour cells to have a short spindle shape, with irregularly shaped heterochromatin rich nuclei. The cytoplasm contained rough endoplasmic reticulum, mitochondria, and well developed intermediate filaments. Only a few intermediate junctions were also observed between neighbouring cells.

FLOW CYTOMETRY

Figure 5 shows the expression of PCNA in relation to the DNA content. As the histogram shows, this cell line demonstrated a diploid pattern. In addition, cells in S phase generally had a high PCNA content, but some cells in G1 and G2/M also showed high PCNA levels. The mean (SD) proportion of cells expressing PCNA was $88.55 \%(2.48 \%)$.

Figure 6 shows the two dimensional display of KU-SS-1 cells labelled with PE-PCNA and FITC-intermediate filament monoclonal antibodies. As shown in fig 6A, a few cells reacted positively with both anti-PCNA and anticytokeratin (right upper square: mean, $6.92 \%$; SD, $2.61 \%$ ), whereas cells that were cytokeratin positive and PCNA negative were rarely seen (right lower square: $0.01 \%$ ). On the other hand, most PCNA positive cells were stained passage 40) into the backs of three SCID mice resulted in the development of tumours. About
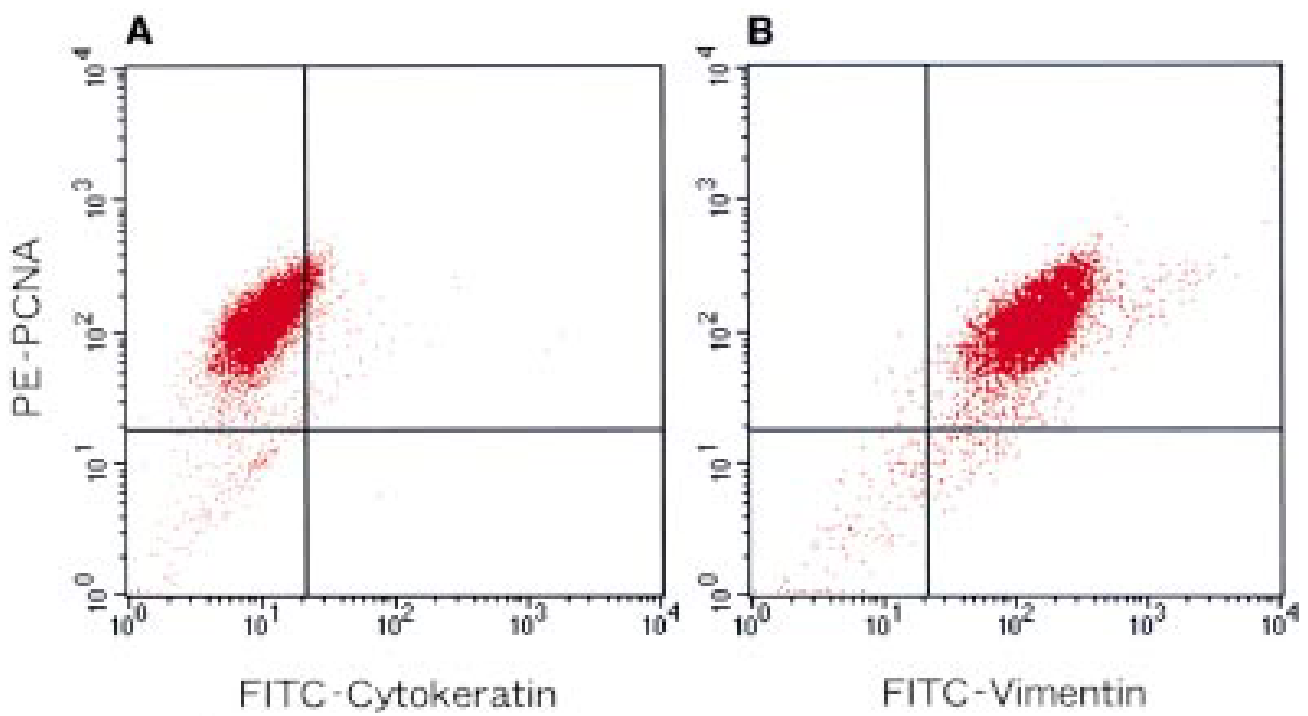

Figure 6 Two colour immunofluorescence staining of KU-SS-1 cells with phycoerythrin (PE) labelled proliferating cell nuclear antigen (PCNA) (y axis) and fluorescein isothiocyanate (FITC) labelled intermediate filament ( $x$ axis). (A) Cytokeratin and PCNA. (B) Vimentin and PCNA. The right upper square displays the cell population that is double positive; the left lower square shows double negative cells. 


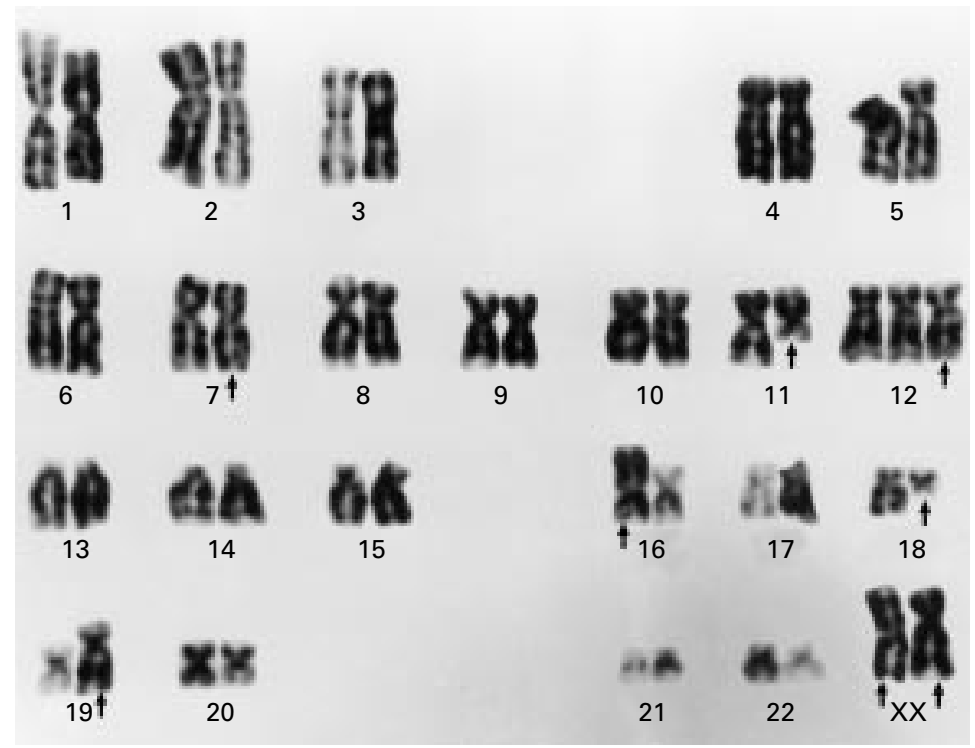

Figure 7 Chromosome analysis of cultured KU-SS-1 cells at passage 30. Arrows indicate abnormal chromosomes.
Table 1 Distribution of the chromosome number

\begin{tabular}{lllrl}
\hline Chromosome number & 45 & 46 & 47 & 48 \\
\hline Number of metaphase cells & 3 & 4 & 42 & 1 \\
& \multicolumn{4}{l}{$(50$ cells counted) } \\
\hline
\end{tabular}

with the antivimentin monoclonal antibody (fig 6B: mean, $88.40 \%$; SD, $1.89 \%$ ). Thus, it is noteworthy that almost all PCNA positive cells reacted with antivimentin and that part of this PCNA positive fraction expressed both vimentin and cytokeratin.

\section{CHROMOSOME ANALYSIS}

Chromosome analysis showed that all chromosomes had a characteristic human pattern and that various numerical and structural chromosome abnormalities were present (fig 7). The chromosome numbers of KU-SS- 1 cells varied from 45 to 48 ( 50 cells counted) with a mode of 47 (table 1). G banding analysis revealed a reciprocal translocation involving chromosome $\mathrm{X}$ and $18, \mathrm{t}(\mathrm{X} ; 18)(\mathrm{p} 11 ; \mathrm{q} 11)$, in every metaphase cell examined. The karyotype of KU-SS-1 cells was considered to be 47 , add $(\mathrm{X})(\mathrm{q} 22), \quad \operatorname{der}(\mathrm{X}) \mathrm{t}(\mathrm{X} ; 18)(\mathrm{p} 11 ; \mathrm{q} 11)$, add (7)(q22), $\mathrm{t}(11 ; 19)(\mathrm{p} 10 ; \mathrm{q} 10), \quad+12, \quad$ add (16)(p13), del (18)(q11).

REVERSE TRANSCRIPTASE POLYMERASE CHAIN REACTION

The KU-SS-1 cell line showed a specific RT-PCR product of $157 \mathrm{bp}$ (fig 8), confirming that this cell line was positive for SYT-SSX chimaeric mRNA. Furthermore, direct sequencing of the RT-PCR products from the KU-SS-1 cell line showed the typical SYTSSX2 fusion point (data not shown).

\section{Discussion}

In our study, it was confirmed by histological, immunohistochemical, cytogenetic, and electron microscopic studies that the KU-SS-1 cell line retained the specific nature of synovial sarcoma. Cytogenetic studies of synovial sarcoma

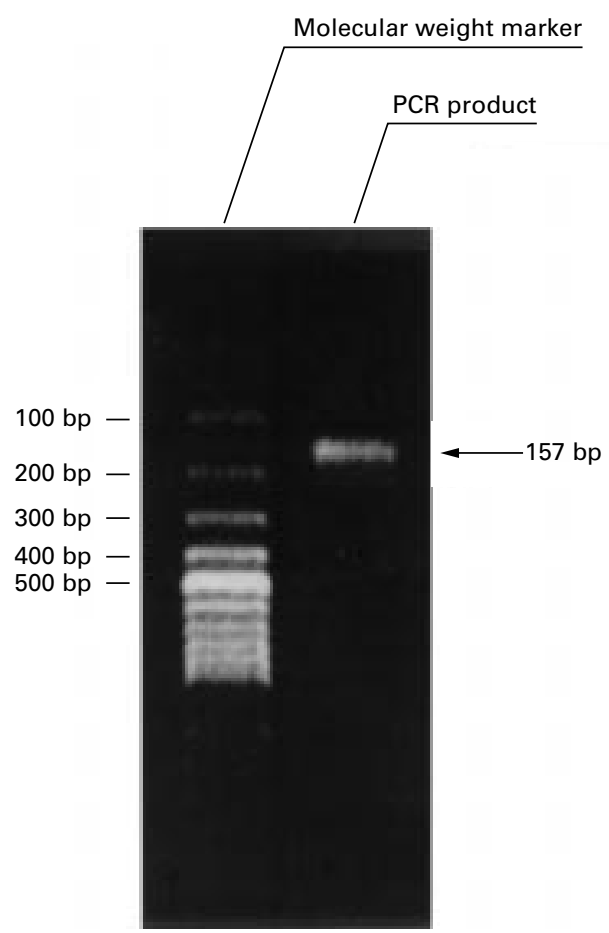

Figure 8 Agarose gel of reverse transcription polymerase chain reaction product obtained from $m R N A$ of KU-SS-1 cells at passage 45. This cell line shows the 157 bp product.

have confirmed that a translocation between chromosomes $\mathrm{X}$ and $18, \mathrm{t}(\mathrm{X} ; 18)(\mathrm{p} 11 ; \mathrm{q} 11)$, is highly specific for synovial sarcoma. . $^{31}$ 36-38 The KU-SS-1 cell line showed this cytogenetic abnormality. In addition, this cell line contained the chimaeric transcript SYT-SSX2, as a result of the $t(X ; 18)(p 11 ; q 11)$ translocation. These results imply that our established cell line originates from synovial sarcoma. ${ }^{33-35}$

Monophasic synovial sarcoma was first described in the late 1960 s. $^{39}{ }^{40}$ It is diagnosed mainly on the basis of microscopic observations that the tumour consists of cells resembling the spindle cell component of a classic biphasic synovial sarcoma. Leader and colleagues ${ }^{41}$ reported that anticytokeratin staining was positive in $40 \%$ of 10 cases of monophasic synovial sarcoma of the spindle cell type. Because cytokeratin is highly specific for epithelial derived tumours, ${ }^{21}{ }^{22}$ they concluded that the tumour cells of synovial sarcoma have a capacity for epithelial differentiation, in spite of the positive reaction to vimentin (a mesenchymal marker). Although immunohistochemical staining for cytokeratin was negative in the parent tumour in our study, the newly established KU-SS-1 cell line became positive to cytokeratin at a later stage (table 2). Therefore, our immunohistochemistry data indicate the possible epithelial differentiation of synovial sarcoma.

Ultrastructural features demonstrated the early epithelial differentiation of tumour cells in monophasic synovial sarcomas with numerous cytoplasmic filopodial like extensions, lumen like structures, basal laminas surrounding some tumour cells, and frequent cell to cell junctions..$^{1-3589}$ By the 40th subculture, the KU-SS-1 cells frequently contained intermedi- 
Table 2 Results of immunostaining

\begin{tabular}{|c|c|c|c|c|c|}
\hline \multirow[b]{2}{*}{ Antigen } & \multicolumn{2}{|c|}{ Original tumour } & \multicolumn{3}{|c|}{$K U-S S-1$ cells ${ }^{*}$} \\
\hline & Human & $\begin{array}{l}\text { SCID } \\
\text { mouse }\end{array}$ & $\begin{array}{l}\text { In vitro } \\
20 \text { th }\end{array}$ & 40th & $\begin{array}{l}\text { In vivo } \\
\text { 40th }\end{array}$ \\
\hline Vimentin & + & + & ++ & ++ & ++ \\
\hline Epithelial membrane antigen & - & - & + & + & + \\
\hline Cytokeratin & - & - & - & + & + \\
\hline
\end{tabular}

$\star 20$ th and 40th refers to the passage number.

+ , Positive cells were detected in parts; ++ , positive cells were detected frequently. SCID, severe combined immunodeficient.

ate junctions, which are seen in epithelial derived tumours. ${ }^{21} 22$ This finding is in accordance with the epithelium like structure of these cells.

A semiquantitative flow cytometry assay was performed using an anti-PCNA monoclonal antibody. PCNA is a cell proliferation marker. ${ }^{26}{ }^{42-45}$ Approximately $89 \%$ of our KUSS-1 cells were positive for PCNA. Nearly $100 \%$ of the PCNA positive proliferating cells reacted with antivimentin and $7.9 \%$ of PCNA positive cells reacted with anticytokeratin. Double staining with anticytokeratin and antivimentin was not performed, however, because nearly $100 \%$ of cells were both vimentin and PCNA positive, $7.9 \%$ of cells were both cytokeratin and PCNA positive, and cytokeratin positive cells were also thought to be positive to vimentin. The positive rate of cytokeratin in this study is considerably lower than that of the HS-SY-II cell line. ${ }^{18}$ The discrepancy in cytokeratin staining between the KU-SS-1 and HS-SY-II cell lines might depend on the character of the original tumour, although both cell lines have an epithelial appearance. Despite the lack of positivity for cytokeratin in the original tumour and the cultured cells during early passages, by the 40th subculture the KU-SS-1 cells were positive for cytokeratin. This supports the theory that synovial sarcoma is a carcinosarcoma like tumour with a dual differentiation capacity: both epithelial and mesenchymal. ${ }^{41} 46-48$

In conclusion, a human synovial sarcoma cell line was established and stably maintained in cell culture for more than 70 passages. This cell line displays the characteristic of epithelial differentiation. Because only a few human cell lines derived from synovial sarcomas have been reported, ${ }^{15-18}$ this cell line will play an important role in the investigation of the nature of this tumour and will contribute to clinical studies. The authors thank Dr Alan Rosen for his assistance in prepar-
ing this manuscript, and SRL Inc (Tokyo, Japan), Sawady Technology Inc (Tokyo, Japan), and Dr Hideo Nakamura (department of tumor genetics and biology, Kumamoto University School of Medicine) for excellent technical assistance.

1 Abenoza P, Manivel JC, Swanson PE, et al. Synovial sarcoma: ultrastructural study and immunohistochemical analysis by a combined peroxidase-antiperoxidase/avidinbiotin-peroxidase complex procedure. Hum Pathol 1986;17:1107-15.

2 Fisher C. Synovial sarcoma: ultrastructural and immunohistochemical features of epithelial differentiation in monophasic and biphasic tumors. Hum Pathol 1986;17: monophas 1008

3 Gabbiani G, Kaye GI, Lattes R, et al. Synovial sarcoma: electron microscopic study of a typical case. Cancer
1971;28:1031-9.
4 Hajdu SI, Shiu MH, Fortner JG. Tendosynovial sarcoma: a clinicopathological study of 136 cases. Cancer 1977;39: 1201-17.

5 Krall RA, Kostianovsky M, Patchefsky AS. Synovial sarcoma: a clinical, pathological, and ultrastructural study of 26 cases supporting the recognition of a monophasic variant. Am $\mathcal{F}$ Surg Pathol 1981;5:137-51.

6 Mickelson MR, Brown GA, Maynard JA, et al. Synovial sarcoma: an electron microscopic study of monophasic and biphasic forms. Cancer 1980;45:2109-18.

7 Miettinen M, Lehto VP, Virtanen I. Keratin in the epithelial-like cells of classical biphasic synovial sarcoma. Virchows Arch B Cell Pathol 1982;40:157-61.

8 Miettinen M, Lehto VP, Virtanen I. Monophasic synovial sarcoma of spindle-cell type: epithelial differentiation as revealed by ultrastructural features, content of prekeratin revealed by ultrastructural features, content of prekeratin and binding of peanut

9 Tsuneyoshi M, Yokoyama K, Enjoji M. Synovial sarcoma: a clinicopathologic and ultrastructural study of 42 cases. Acta Pathol fpn 1983;33:23-36.

10 Stuer J. Eine ungenwohnliche Geschwulst der Ellbogengelenksgegend. Rinaug Diss Wuerzburg 1893.

11 Fernandez EA, Zapata JE. Monophasic mesenchymal synovial sarcoma: its identification by tissue culture. Cancer 1981;47:628-5.

12 Ichinose H, Powell L, Hoerner HE, et al. The potential histogenic relationship of the peripheral nerve to synovioma. Cancer Res 1979;39:4270-3.

13 Hajdu SI, Lemos LB, Kozakewich H, et al. Growth pattern and differentiation of human soft tissue sarcomas in nude mice. Cancer 1981;47:90-8.

14 Nojima T, Wang YS, Abe S, et al. Morphological and cytogenetic studies of a human synovial sarcoma xenotransplanted into nude mice. Acta Pathol fpn 1990;40:486-93.

15 Ishii S, Yamawaki S, Saki T, et al. Characteristics of human soft tissue sarcoma in xenografts and in vitro. Clin Orthop 1983;173:251-61.

16 Noguchi S, Ueki T, Kawauchi S, et al. Establishment and characterization of a new synovial sarcoma cell line, SN-SY-1: special reference to bcl-2 protein and SYT-SSX1 hybrid transcript. Int $\mathcal{F}$ Cancer 1997;72:995-1002.

17 Ponten J, Saksela E. Two established in vitro cell lines from Ponten J, Saksela E. Two established in vitro cell lines from
human mesenchymal tumours. Int $¥$ Cancer 1967;2:43444.

18 Sonobe $\mathrm{H}$, Manabe Y, Furihata M, et al. Establishment and characterization of a new human synovial sarcoma cell line, HS-SY-II. Lab Invest 1992;67:498-505.

19 Hsu SM, Raine L, Fanger H. Use of avidin-biotinperoxidase complex (ABC) in immunoperoxidase

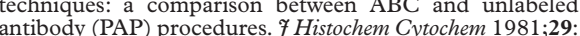
577-80.

20 Tsujimoto M, Ueda T, Nakashima H, et al. Monophasic and biphasic synovial sarcoma: an immunohistochemical study. Acta Pathol fpn 1987;37:597-604.

21 Goddard MJ, Wilson B, Grant JW. Comparison of commercially available cytokeratin antibodies in normal and neoplastic adult epithelial and non-epithelial tissues. 7 Clin Pathol 1991;44:660-3.

22 Moll R, Franke WW, Schiller DL. The catalog of human cytokeratins: patterns of expression in normal epithelia, tumors and cultured cells. Cell 1982;31:11-24

23 Brozman M. Immunohistochemical analysis of formaldehyde- and trypsin- or pepsin-treated material. Acta Histochem 1978;63:251-60.

24 Kurki P, Ogata K, Tan EM. Monoclonal antibodies to proliferating cell nuclear antigen (PCNA)/cyclin as probes for proliferating cells by immunofluorescence microscopy and flow cytometry. F Immunol Methods 1988;109:49-59.

25 Landberg G, Tan EM, Roos G. Flow cytometric multiparameter analysis of proliferating cell nuclear antigen/cyclin rameter analysis of proliferating cell nuclear antigen/cyclin 1990;187:111-18.

26 Landberg G, Roos G. Expression of proliferating cell nuclear antigen (PCNA) and Ki-67 antigen in human malignant hematopoietic cells. Acta Oncol 1991;30:917-19.

27 Waseem NH, Lane DP. Monoclonal antibody analysis of the proliferating cell nuclear antigen (PCNA): structural conservation and the detection of a nucleolar form. $\mathcal{F}$ Cell Sci 1990;96:121-9.

28 Drach J, Gattringer C, Glassl $\mathrm{H}$, et al. Simultaneous flow cytometric analysis of surface markers and nuclear Ki-67 antigen in leukemia and lymphoma. Cytometry 1989;10: 743-9.

29 Schwarting R, Gerdes J, Niehus J, et al. Determination of the growth fraction in cell suspension by flow cytometry using the monoclonal antibody Ki-67. F Immunol Methods 1986;90:65-70.

30 Limon J, Mrozek K, Mandahl N, et al. Cytogenetics of synovial sarcoma: presentation of ten new cases and review of the literature. Genes Chromosomes Cancer 1991;3:338-45.

31 Phan Thu A, Zajac V, Kuliffay P, et al. Karyological and isoenzyme characterization of established human sarcoma cell lines. Neoplasma 1980;27:557-66.

32 Turc-Carel C, Dal Cin P, Limon J, et al. Involvement of chromosome $\mathrm{X}$ in primary cytogenetic change in human neoplasia: nonrandom translocation in synovial sarcoma. Proc Natl Acad Sci U S A 1987;84:1981-5.

33 Clark J, Rocques PJ, Crew AJ, et al. Identification of novel genes, SYT and SSX, involved in the $\mathrm{t}(\mathrm{X} ; 18)(\mathrm{p} 11.2 ; \mathrm{q} 11.2)$ translocation found in human synovial sarcoma. Nat Genet 1994;7:502-8. 
34 Fligman I, Lonardo F, Jhanwar SC, et al. Molecular diagnosis of synovial sarcoma and characterization of a variant 5 Shipley J, Crew J, Birdsall S, et al. Interphase fluorescence in situ hybridization and reverse transcription polymerase chain reaction as a diagnostic aid for synovial sarcoma. $\mathrm{Am}$ 7 Pathol 1996;148:559-67.

36 Griffin CA, Emanuel BS. Translocation $(\mathrm{X} ; 18)$ in a synovial sarcoma. Cancer Genet Cytogenet 1987;26:181-3.

37 Nilbert M. Molecular and cytogenetics of soft tissue sarcomas. Acta Orthop Scand 1997;68:60-7.

38 Smith S, Reeves B, Wong L, et al. A consistent chromosome translocation in synovial sarcoma. Cancer Genet Cytogenet 1987;26:179-80.

39 Cadman NL, Soule EH, Kelly PJ. Synovial sarcoma: an analysis of 134 tumors. Cancer 1965;18: 613-27.

40 Mackenzie DH. Synovial sarcoma: a review of 58 cases. Cancer 1966;19:169-80.

41 Leader M, Patel J, Collins M, et al. Synovial sarcomas: true carcinosarcomas. Cancer 1987;59:2096-8.

42 Asakura S. DNA-PCNA dual-staining analysis of bone and soft tissue tumors with flow cytometry. F Orthop Sci 1997; 2:203-9.
43 Garcia RL, Coltrera MD, Gown AM. Analysis of proliferative grade using anti-PCNA/cyclin monoclonal antibodies in fixed, embedded tissue. Am f Pathol 1989;134: 733-9.

44 Oda Y, Hashimoto $\mathrm{H}$, Takeshita $\mathrm{S}$, et al. The prognostic value of immunohistochemical staining for proliferating cell nuclear antigen in synovial sarcoma. Cancer 1993;72: cell nucl $478-85$.

45 Woods AL, Hall PA, Shepherd NA, et al. The assessment of proliferating cell nuclear antigen (PCNA) immunostaining in primary gastrointestinal lymphomas and its relationship to histological grade, $\mathrm{S}+\mathrm{G} 2+\mathrm{M}$ phase fraction (flow cytometric analysis) and prognosis. Histopathology 1991;19: $21-7$.

46 Ghadially FN. Is synovial sarcoma a carcinosarcoma of connective tissue. Ultrastruct Pathol 1987;11:47-51.

47 Miettinen M, Virtanen I. Synovial sarcoma-a misnoma. Am f Pathol 1984;117:18-25.

48 Murray MR, Stout AP, Pogogeff IA. Synovial sarcoma and normal synovial tissue cultivated in vitro. Ann Surg 1944;120:843-51.

\section{WHAT'S YOUR VIEW?}

Pathology Interactive: useful or useless?

To make Pathology Interactive more useful tool to help you in your CPD

... we need your views

Please take time to complete a self completion questionnaire and fax it back to us

Questionnaire available for printing out on:

Pathology Interactive CD Vol 1 issue 3 (Dec 1999)

Pathology Interactive CD Vol 22000

Fournal of Clinical Pathology website - www.jclinpath.com

Fax completed forms to Natalie Davies, Editorial Assistant, Journal of Clinical Pathology (+44 (0)207383 6668).

Your time and help are appreciated. We especially thank all those ACP members who returned questionnaires circulated in the September 1999 journal issue for their valuable feedback.

Pathology Interactive 2000 offers up to three CPD credits per article; later issues feature case study and picture quiz formats 